$11^{\text {th }}$ ICEEPSY 2020

The International Conference on Education \& Educational Psychology

\title{
IMPLEMENTATION OF ACTIVE AGEING POLICY IN THE MORAVIAN-SILESIAN REGION
}

\author{
Šárka Dořičáková (a)*, Pavlína Pospíšilová (b) \\ *Corresponding author \\ (a) Šárka Dořičáková, University of Ostrava, Faculty of Social Studies, Českobratrská 16, 70200 Ostrava, Czech \\ Republic, sarka.doricakova@osu.cz \\ (b) Pavlína Pospíšilová, University of Ostrava, Faculty of Social Studies, Českobratrská 16, 70200 Ostrava, Czech \\ Republic, pavlina.pospisilova@osu.cz
}

\begin{abstract}
Affecting the demographic structure, population ageing is a social challenge. Active ageing aims at making use of the potential of senior citizens. The submitted research focuses on the way municipalities and city districts in the Moravian-Silesian Region implement the policy of active, healthy and dignified ageing. The research strategy was qualitative, the data were obtained by semi-structured interviews with representatives of municipalities and city districts. The research sample was chosen by means of simple sampling based on the following criteria: the informant was a representative of the municipality/urban district within the Moravian-Silesian Region who gave his/her consent to participate in the research. The research resulted in a long list of activities for senior citizens. The municipalities support the activities mostly in a financial manner. They take part in organizing social and educational events, too. Territorial units endeavour to make good living conditions for citizens, ensure transport to/from the doctor's office for them, etc. The active ageing policy in larger administrative units and urban districts in the MoravianSilesian Region is encoded in strategic documents. However, smaller units do not dispose of such documents although they do implement this policy. All activities aim at prolonging the time senior citizens live in their natural environment.
\end{abstract}

2672-8141 (C) 2020 Published by European Publisher.

Keywords: Active ageing, implementation, demographic ageing. 


\section{Introduction}

According to the ČSÚ (2020), the share of persons over 65 in the population was $19.7 \%$ (the population from 65 to 79 reached $14.2 \%$ and the population over 80 reached $5.6 \%$ ) in the European Union (28 countries) in 2018. Given this, multiple measures have been taken to support active ageing policies at the international level (for example, UN Principles for Older Persons, 1991; The 2002 Madrid International Plan of Action on Ageing, 2002). Moreover, the European Union declared the year 2012 the European Year for Active Ageing and Solidarity between Generations. The data on ageing population in Europe are presented in Figure $1 .^{1}$

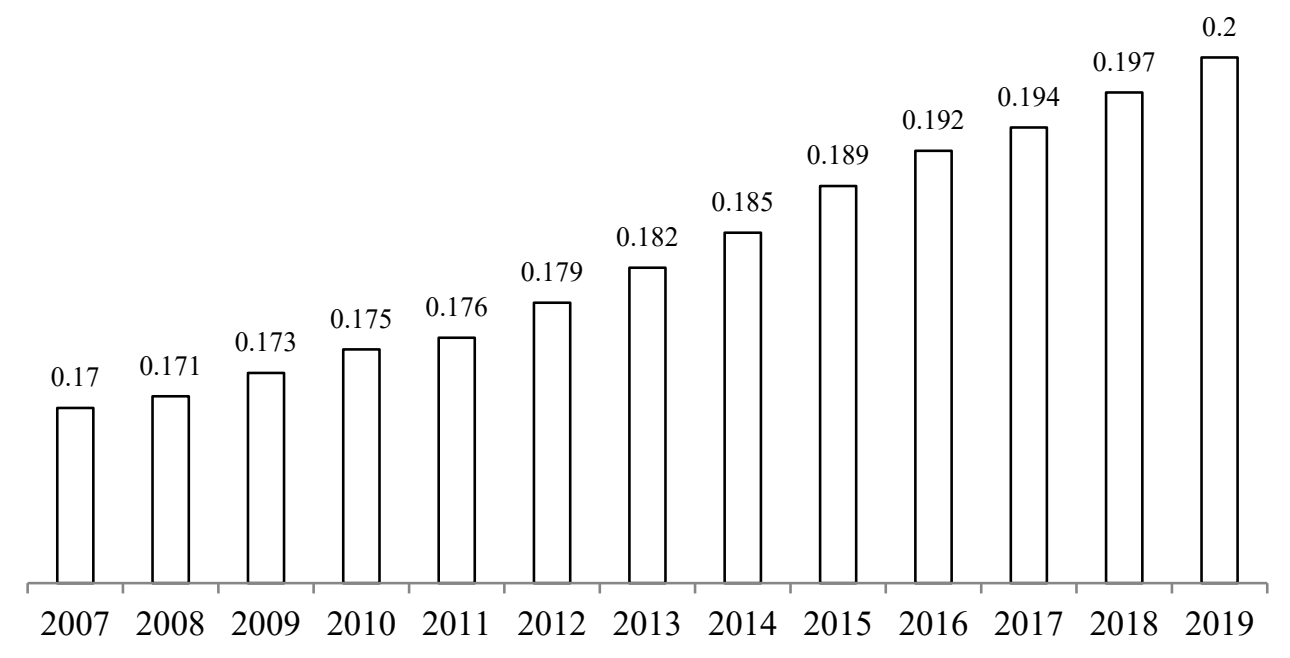

Figure 01. Share of persons over 65 in E Source: Eurostat (2020), adapted

The Czech Republic has also gone through demographic changes. In 2018, the share of persons from 65 to 79 was $15.2 \%$ while the population over 80 years reached $4.0 \%$. The former category was above the European average, while the latter category is below the average (ČSÚ, 2019).

Ageing and old age tend to be viewed negatively, which - to a large extent - has been caused by the mass media that generally present old people as unfit and passive, as recipients of services and benefits, as defenceless victims of frauds and crimes (Čevela et al., 2012; Quadagno, 2017; Swinnen \& Stotesbury, 2012). The myths and prejudices have been surveyed by many experts (Haškovcová, 2010; Sýkorová 2007). Our views of senior citizens are often obsolete and ignoring the fact that modern seniors represent a heterogeneous group of almost two million persons and that the heterogeneity will grow even stronger (Strategy on Preparation for Ageing 2019-2025, n.d., p. 2). Assessing people by their chronological age is challenged by two intellectual factors: (1) Viewing old age as anticipation of disability, considering only two options: whether an individual can work or not. (2) Giddens' notion of ageless society. For example, Haškovcová (2010) or Čeledová et al. (2016) use this concept. It says that the extent and intensity of social events cannot be judged by one's age but rather his/her health status (disability) (Bočková \& Vojtíšek, 2017, p. 50). Combination of activity and old age as well as an

\footnotetext{
${ }^{1}$ The graph covers 28 member states from 2013 to 2020 .
} 
idealized concept of old age are common in the postmodern society. The concept of active ageing can be understood as a result of modern time of power and knowledge that has emerged in the context of demographic trends related to the so-called population ageing (Hasmanová Marhánková, 2013, p. 12).

The elderly are - thanks to a developed healthcare system, growing income, education, living conditions and other factors - often in a good health state. They are active and interested in work even in retirement. They encounter barriers in the form of inappropriate conditions or structural obstacles that may stop them from making use of their potential (Čevela et al., 2012). Understanding both their potential as well as physical limits helps the policymakers develop successful social policy of active ageing. The care, stemming from humanistic ideas, should support the elderly in their working and social environment as long as possible (Tomeš, 2018). While physical and mental factors of a person tend to change gradually, social factors change almost immediately. For society, a person becomes an anonymous pensioner whose previous professional career is no longer valued and who gradually loses importance. That is why social factors should not be neglected (Bočková \& Vojtíšek, 2017). Concerning the abovementioned, the article aims at presenting the ways the municipalities in the Moravian-Silesian Region (hereinafter also "MSR") implement the active ageing policy - the ways (besides social services) they strive for active, healthy and dignified ageing of their citizens.

\section{Problem Statement}

Czech and European population has been and will be ageing. According to the document Projekce obyvatelstva České republiky 2018-2100, it will undergo dramatic changes not in the size but in the age structure. In the course of the next decade, the group over 65 will transform most. It is estimated to account for $29.5 \%$ of the population in 2100 (ČSÚ, 2018). Population ageing in the Czech Republic is discussed at national as well as local level. Rada vlády pro seniory a stárnutí populace (Government Council for Older Persons and Population Ageing, hereinafter referred to as the "Council") was established in 2006 as an advisory body of the government as a follow-up to the implementation of National Programme of Preparation for Ageing for the Period 2003-2007 (2002) in order to treat the issue of older people and ageing in the Czech Republic at the highest level of state administration and to treat active ageing policy activities (MPSV, 2015). Other strategic documents on active ageing policy in the Czech Republic were National Programme of Preparation for Ageing for the Period 2008-2012 (2008) and National Action Plan of Positive Ageing for the Period 2013-2017 (2014), followed by Strategy on Preparation for Ageing 2019-2025 (n.d.). The Ministry of Labour and Social Affairs implements the active ageing policy at the level of national departments and interdepartmental collaboration; however, it is also necessary to include important actors at regional and local level (local communities, the non-profit sector, clubs and research organizations).

Regional administration and self-government are the chief actors of implementation of policy on active ageing and old age. At regional level, the project Implementace politiky stárnutí na krajskou úroveň has been implemented recently. It focuses on systemic and methodological support for the development of activities and implements the preparation for ageing at national, regional and local level (MPSV, 2019). Its specific goal is, inter alia, development of activities aimed at preparing for old age. Given that, the submitted study focuses on the implementation of the principles of active positive ageing 
policy at local level. We decided to survey the Moravian-Silesian region the conditions of which are historically unique. The run-down of heavy industry and the environment have significantly affected its demography. In 2015, the population of the MSR totalled 1213 311, while at the end of 2017 it decreased to 1205 866. In terms of age, the group over 65 grew larger: $18.1 \%$ in 2015 , while $19.2 \%$ at the end of 2017 (ČSÚ, 2018). In 2017, there were 231,526 people over 65 in the MSK. The active social policy of the MSR is anchored in the document Strategy for Developing the Moravian-Silesian Region for the Period 2019-2027 (2019). The demographic development and population ageing belong to topical issues. Another strategic document is Draft of the Medium-Term Plan for the Development of Social Services in the Moravian-Silesian Region for the Years 2021-2023 (2019), which, however, focuses on persons in the need of professional care and assistance in the form of networking social services under the Act No. 108/2006 Coll., on Social Services. Previous studies have focused on an older person-social service relation (services for a particular target group, their family members and close persons who act as their informal caregivers) but our research focuses on the so-called blindspot, i.e. on active positive ageing in the Moravian-Silesian Region.

\section{Research Questions}

The research question, based on the research problem and goal, is: How do municipalities and city districts in the MSR declare the implementation of the policy of active, healthy and dignified ageing in their territory?

\section{Purpose of the Study}

The study aimed at searching and describing how chosen municipalities and city districts implement the policy of active, healthy and dignified ageing with regard to the new document Strategy on Preparation for Ageing 2019-2025 which is based on the project Implementace politiky stárnutí na krajskou úroveň. Areas related to social services for older people, anchored in Národní strategie rozvoje sociálních služeb na období 2016-2025 (Pospíšil, 2015), were excluded. Destigmatization of old age and ageing as well as support for the implementation of active, healthy and dignified ageing in the MSR were partial application goals of our research.

\section{Research Methods}

With regard to the fact that we focused on individual perception and interpretations, we found the constructivist paradigm (Lincoln et al., 2014) the most expedient. To meet the stipulated goals, we applied the qualitative method of the Grounded theory to analyze the data (Padgett, 2017). We read the acquired transcripts several times and analysed them, using open coding techniques and notes on emerging interpretations and conceptualizations (Howard \& Berg, 2016). Thus, we analysed the material, following the Generic inductive qualitative approach (Hood, 2014), or the General coding paradigm (Maxwell, 2005). The Grounded theory copies Charmaz approach that is based on the interpretative paradigm and constructivist principles (Hubík, 2006). The data were analyzed via ATLAS.ti8, which reveals the complex hidden structure of the data and their mutual meanings. 
The data were collected by way of semi-structured interviews that were recorded and transcribed verbatim (Moorse, 2009). The research sample was made by way of simple deliberate sampling based on a stipulated criterion, that is an authorized representative of the municipality/city district in the MoravianSilesian Region. The semi-structured interviews were conducted by students of the follow-up Master's studies of Social Work, Faculty of Social Studies, University of Ostrava. They contacted municipalities in the MSR to ask them for participation. As soon as 32 interviews (10\% of municipalities in the MSR) were collected, the obtained data were analyzed. The interviews took place in safe conditions so that the informants could be open. Due to the state of emergency, declared by the Czech government, some interviews were conducted online in order to protect the health of both the researcher and the informant. The informants were informed about the research aim and the possibility to interrupt or discontinue their participation any time. They were assured that all data were anonymized. The following table presents the sociodemographic characteristics of the informants involved. As one of the informants did not give his consent to the use of his data, the table includes information on 31 informants only. Mining the information was the first part of the interviews; the second part was the core of the interview, the very research topic.

Table 01. Sociodemographic features of the informants

\begin{tabular}{|l|l|l|l|l|}
\hline Authorities total & No. of women & No. of men & $\begin{array}{l}\text { Average age of } \\
\text { informants }\end{array}$ & $\begin{array}{l}\text { Average time on the } \\
\text { work position }\end{array}$ \\
\hline 31 & 25 & 6 & 48,9 & 8,23 \\
\hline
\end{tabular}

Source of data: own research, 2020

Table 02. Work position of the informants

\begin{tabular}{|l|}
\hline Mayor \\
\hline Deputy mayor \\
\hline Concillor \\
\hline Officer \\
\hline Social worker \\
\hline Head of the Social Affairs departments \\
\hline Worker of the Social Affairs departments \\
\hline Other representatives \\
\hline Social services methodology specialist \\
\hline
\end{tabular}

Source of data: own research, 2020

We subsequently analyzed the transcribed data, using open, axial and selective coding techniques. Within the open coding, we read the texts several times in detail, made them into smaller meaning units and assigned terms-codes to them. During the analysis, we reviewed the codes. The index of codes, which we sorted into meaning units, was made in this manner. Subsequently, we categorized the codes, making categories and subcategories. We gained 123 codes that we grouped into 12 categories on the basis of their content. Each category was named in order to logically refer to the relevant phenomenon. In the first phase of open coding, we abstracted codes, merged categories and subcategories, their features and dimensional scope. 


\section{Findings}

After open coding, we went on with axial coding, searching for relations between individual categories. Axial coding is a complex inductive-deductive process. We matched individual categories in a broader context of applied social phenomena. We compared close and distant phenomena. Finally, we interconnected the categories to make a set of relationships according to the paradigmatic model (shown in Table 3).

Table 03. Paradigmatic model focused on social activities related to the support of active, healthy and dignified ageing of the population

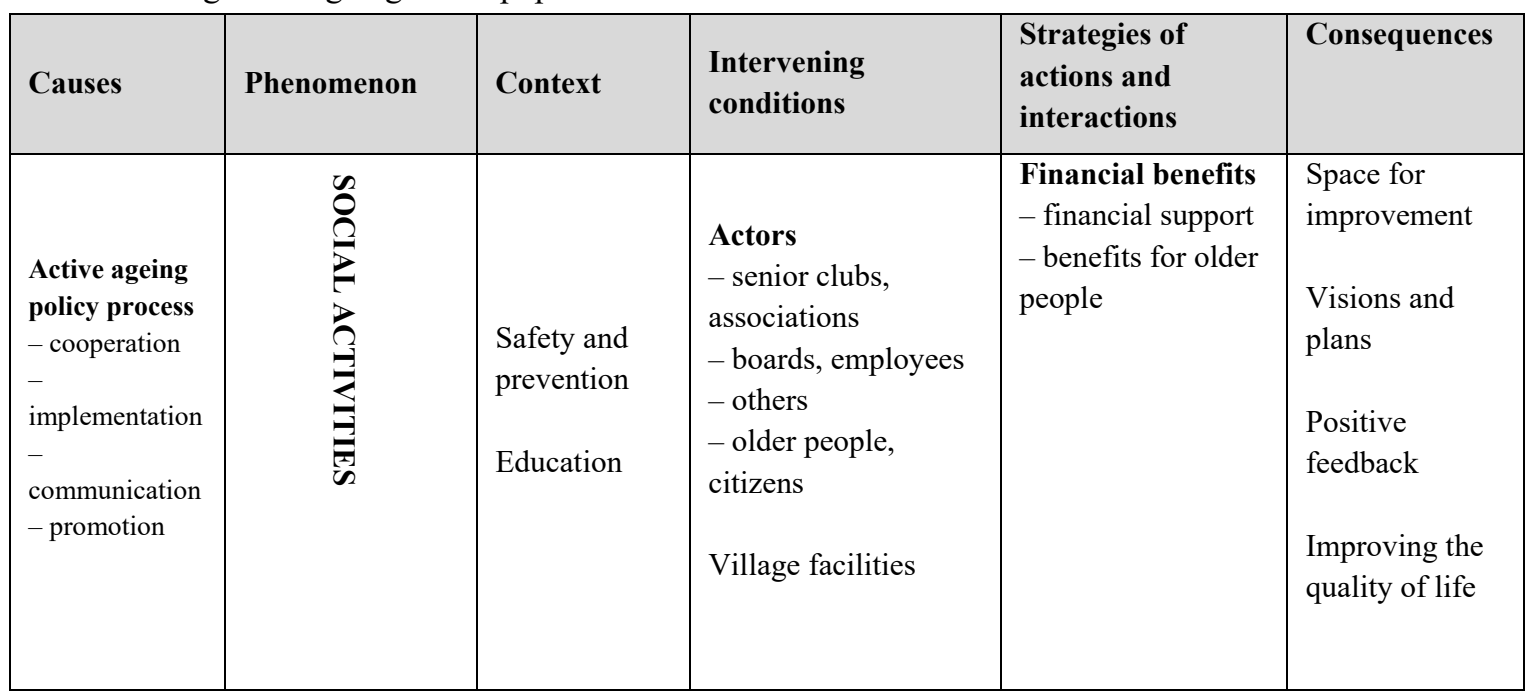

Source of data: own research, 2020

Through axial coding, we established the basis for selective coding and integrated the obtained categories into the Grounded theory (Strauss \& Corbin, 1997). The basic elements for the emerging theory were categories and their dimensions. Based on the paradigmatic model, we related the categories to a central category; then we related the categories at dimensional level and verified their relations on the basis of the data.

We created several important categories: social activities, the process of active ageing policy implementation, financial benefits.

The main category was Social Activities; they were both important and diverse. The informants from the municipalities interpreted them as follows: "Well, of course, the other cultural events, the society-wide ones, which are presented and everyone from the village is welcome there, yeah" (1:1768). "Well, otherwise, we organize a ball for them annually and such various events, sports games for older people, and so on" (1:1078). "Well, we take turns, one year a lecture, an interesting one, and next year a theatrical performance, yeah, here in the house of culture..." (1:1795). " ...so, something is organized for them within the municipality, whether joint actions in cooperation with the cultural committee... Or individual awards or individual visits to persons celebrating their jubilees" (1:577). "They organize plenty of exhibitions and vernissages, where they make various floral collages, or in topical terms, they, for example, bake strudels in autumn..." (1:570). Intense intergenerational cooperation is seen during 
social events: "There is real cooperation between schools and kindergartens. In case of holidays such as the Women's Day, the Children's Day, then children go there" (1:1546). "Then there is some introductory cultural programme, we try to involve mainly local children there in it..." (1:1787). Senior citizens also visit kindergartens and intergenerational relations thanks to discussions or projects come into existence. It is clear that the informants perceive that mutually beneficial. "They go to kindergarten regularly and read for children before they go to bed. Together, they enjoy the event of making a nature garden, they sow seeds, plants, flowers... Well, vice versa, they bake gingerbread and strudels in autumn, the senior club attends the Christmas get-together in the kindergarten. And vice versa, the kindergarten visits the senior club at least once a month. It is always such a mutually pleasant gathering (1:1714). According to the statements, the intergenerational cooperation is related to volunteering and projects of non-profit organizations. "So Adra volunteers are involved in the project of reading for children in kindergartens..." (1:1206). "The time of cooperation has begun. The elderly recycle - they knit blankets, socks, caps for ill Malawian children as well as for the Czech-Slovak hospital in Fanuel, Malawi" (1:906). Visits to persons celebrating their jubilees is an important social activity, too. Two forms can be seen: First, organizing events, usually accompanied with further cultural program, where persons celebrating important anniversaries are invited. "Every year, the municipality always organizes that for all senior citizens over 65. There is always a nice cultural program where the kindergarten, kindergarten children perform and then a professional musical program" (1:1737). "Well, actually there's the Day of Older Persons, so we always have such a celebration. All older persons are invited. And especially those celebrating an important anniversary" (1:1471). "Other regular activities of the city include the Meeting persons celebrating an important anniversary with a concert or a theatre performance together with personal congratulations and a small gift from the city management" (1:356). Second, a visit to a senior birthday person in his/her home. "Above 80, we go to congratulate in households, it is actually the age of 80, 85, 90 and we go annually above 90" (1:767). "We go on behalf of the municipality, we attend older persons who reach some life jubilee" (1:204). "We visit seniors who reach some life jubilee" (1:739). The social activities include handicraft, too. "... also handiwork. In the course of Christmas and Easter, the material is bought from subsidies and we make candlesticks, eggs and various products." (1:499). "... One can take advantage of morning art courses that are offered namely to older persons by local Basic art school" (1:418). The opportunities for social life of older persons are obviously developed and diverse, which the senior citizens appreciate. "It's a very well-perceived event with a lot of positive feedback. I am really happy about that, that we are doing well" (1:500). "Well, it's also a pretty nice event. And they like it because the program ends and if they are strong enough, they keep on singing" (1:1472). "Yes, the feedback about this event has always been very good" (1:1790). "We try to make it varied for the senior citizens" (1:1072). "So, we meet, I would say, their contentment with the offer that is actually here" $(1: 268)$.

In the paradigmatic model, the process of active ageing policy implementation represents causal conditions. This category is important because it includes a range of social activities that support active, healthy and dignified ageing. The below-stated passages from the interviews support this finding. Cooperation of individual actors is the most significant factor of the active ageing policy implementation. It results in the existence of various social, sporting and cultural events for seniors. "There are several 
chosen activities, such as pétanque, skittles, darts, and so on. Well, there are actually about ten to fifteen teams from various city districts at that event" (1:46). "It works, mainly, I don't know, for example, a senior club with firefighters, yeah, when they build a maypole, so the mutual help is there. Or they support each other by viditing their club events. This is how it works" (1:214). "The Committee for Civic and Social Affairs, in cooperation with the municipality and local clubs, organizes activities for target groups of citizens, such as cultural events for various age groups" (1:653). "So, the cooperation is really great. It is grounded mainly in their methodological help... we do not manage to study everything and watch the changes and the girls from the social department are always very helpful" (1:869). Due to the geographical location, the actors in the region cooperate also with their foreign counterparts - with villages beyond the border with Poland. "I would like to mention our joy, that is the senior exchanges within the framework of our town partnership" (1: 455). "So, there are a lot of, well, we call them our Poles, so they also have many, like in their clubs, and so on, they have a lot of those activities and they realise their potential here" (1:1194). The Moravian-Silesian Region and community planning are essential in implementing the active ageing policy. According to the informants, community planning holds a strong position. "A number of those activities for senior citizens are also organized from the position of individual city districts, we all meet here at municipal level within the community planning" (1:98). "Yes, the working group Senior citizens. Its members are registered and licenced social service providers as well as non-profit organizations, social workers under the municipality or the lay senior public" (1:280). Cooperation with the Moravian-Silesian Region relates mainly to financing the implementation process and activities. "... We cooperate with the region and with the Ostrava municipal authority. In fact, everything in this field depends on finances" (1:1672). "The Moravian-Silesian Region but it's not just about their grant. It is also about our grants, it is given on some benchmark" (1:195). The statements prove that smaller municipalities do not dispose of a worked-out strategic document on active ageing policy; nevertheless, they implement the policy with regard to current needs. "Smaller municipalities solve the topical situations and problems in the senior population flexibly" (1:319). "Well, we probably do not have a document as such that would be explicitly called implementation of the ageing policy, we certainly do not have it" (1:815). "Mmm, I wouldn't say it's too organized" (1:524). The informants emphasize communication between actors in the process of the active ageing policy implementation. "We communicate a lot or we get stimuli from the older persons that they maybe tell us it would be good to visit that senior citizen, so the older persons more or less know each other a lot, so we get the information from the senior citizens" (1:163). "We strive for a high degree of communication with those seniors..." (1:162). "We just like to spend time with the older people in the way that we organize discussions where citizens can come and sit with us over a cup of tea and coffee from time to time. We analyze there what can be done better. They come up with suggestions for what the municipality itself could do for them" (1:449). "... It proved successful for us, probably communication proved successful for us" (1:828). Communication and cooperation are closely related to awareness and promotion of social activities. "For many years, the city has organized the Day of the Town and The Day of Social Services. Individual services and organizations have introduced themselves here" (1:361). "... Free possibility of self-presentation in the city newsletter" (1:478). "Yes, on the one hand, the official notice board works, we also have... bulletin boards... which are scattered all over the district. Information is actually provided or given there" (1:589). "Then classic posters, announcements on PA. Yeah, and sometimes they 
go around with leaflets so that there is some information in each letterbox." "Another information channel is the PA system, there are also websites, municipality Facebook, leaflets, posters." The process of active ageing policy implementation also includes mapping the needs of the population. According to the informants, much attention is paid to it. "We also have a debate there, a discussion with the senior citizens, what they would like to have in the municipality, how satisfied they are, what they would not like" (1:33). "Well, it is definitely good to make such surveys, also with regard to the fact that, for example, someone in the municipality will think about it. Hey, do we do something about it, do not we. We can do more, we cannot" (1:75). "Yes, the municipality keeps on paying permanent attention to the needs of the senior population. Over the years, it has sought for their needs and ways to meet them" (1:278). "Notably, we started to make the rounds of really older people in the municipality and see if they need anything" (1:660).

The interviews showed that social activities were supported mostly in the form of financial benefits "... so we support the events for senior citizens financially" (1:705). "In my opinion, all in all, the municipality also supports them, they apply for a grant every year" (1:818). "We create conditions, participate financially in renting the rooms, pay for energy, and also pay the coordinators of given activities from the group of senior citizens who work on contracts-for-work or contracts-for-activity." The financial aid is accompanied by further benefits, among which free premises for club gatherings or events are important. "Each district has a senior club which has a somehow reduced rent for those premises" (1:99). "We have made our meeting room accessible for them, so the committee meets here" (1:816). "... The senior club may use the premises for its activities, for its work free, free of charge" (1:1238). "The municipality provides them with the so-called clubhouse free of charge" (1:670). The financial support is provided from the municipal budget and must be approved by the municipal council. "Every year, the council approves a grant for those senior events" (1:224). "All these activities are paid from the city budget and their offer again aims at a broad spectrum of seniors citizens" (1:977). The informants found the financial benefits, including reduced entrance fees, for older people important. "Yes, entrance fees are reduced for senior citizens" (1: 315). "I know that permanent passes were used in theatres or swimming pools, yeah, as well. So all of that is covered by the municipality for them" (1:989). Furthermore, there are, for example, education allowances, reduced rent in the dwellings for the elderly, cheaper public transport. "And we also partly cover the tuition fees at senior academies" (1:711). "We also have significantly reduced prices of public transport, so the senior citizens can buy a year ticket for two hundred crowns, I guess" (1:1155). Transportation service for seniors is another financial benefit. "We also joined the senior express" (1:545). "The municipality contributes to the Senior Transportation, too" (1:334). "Senior taxi is adapted to this and a low charge is also a priority" (1:255). It is an existing taxi service that provides its services on favourable conditions. "The taxi service is ready and well established and has earmarked one car and one employee for our district" (1:595). "Well, and with that card, he'll actually identify himself to the taxi driver" (1:548). Alternatively, a car is owned by the municipality: "In us, it is directly a car owned by our district" (1:1524). This service is provided to seniors who have to arrange for necessities at offices, doctors, etc. "We have a senior taxi, financially supported by the municipality, which transports seniors within and around the municipality, to the doctor, to the offices" (1:708). 
Financial benefits are a good tool to support the activities of senior citizens, to include them in the municipality and to educate them. "Then even those city districts were thinking about keeping the elderly active by making transportation more accessible or affordable for them..., which can also play a role at economic level in a way" (1:103). "We support senior activities by discounts at a swimming pool, in a salt cave, sauna, Russian skittles, pétanque" (1:709).

\section{Conclusion}

Our survey has shown that municipalities in the Moravian-Silesian Region implement the active, healthy and dignified ageing policy to meet the pressing needs of their people. They focus on social activities of many types, e.g., cooperation between relevant actors (mainly local authorities, interest groups, senior clubs, citizens and the elderly themselves) who have financial as well as organizational relationships, making an effective system that significantly improves the quality of life of the elderly. The activities give rise to intergenerational gatherings that the informants consider a crucial component of social life of the elderly. The informants talked about the risk of social isolation of senior citizens. Municipalities prevent it by encouraging them to participate in active ageing - they involve them in planning and organizing activities. Finances are problematic. Smaller territorial units are usually neither involved in community planning nor do they make strategic documents for the target group of seniors. On the other hand, larger territorial units are involved in these processes and have therefore access to the regional budget. According to the informants, higher grants, subsidies, other funds and their facilitation might improve the situation. The actors would have more opportunities to support active, healthy and dignified ageing. The informants also mentioned better municipal facilities (accessibility, sports facilities), including barrier-free housing for the elderly. Through the policy of active, healthy and dignified ageing, the state aims at supporting activity in older people living in their natural community and at preventing their exclusion or institutionalization in residential social services. At the same time, it reflects their needs because researchers (e.g., Vávrová, 2015) show that residential social services are, according to their users, only the very last option. It is one of the most difficult life decisions that should be avoided as long as a person is autonomous and self-sufficient.

\section{Acknowledgments}

The article was supported by grant No. SGS01/FSS/2020 Implementace politiky aktivního stárnutí v Moravskoslezském kraji [Implementation of Active Ageing Policy in the Moravian-Silesian Region].

\section{References}

Bočková, L., \& Vojtíšek, P. (2017). Potenciál starších osob a senioru pro spolecnost [The potential of the elderly and the elderly for society]. In I. Tomeš, \& K. Šámalová (Eds.), Sociální souvislosti aktivního stář́ [Social Aspects of Active Old Age] (pp. 49-74). Univerzita Karlova, Karolinum.

Čevela, R., Kalvach, Z., \& Čeledová, L. (2012). Sociální gerontologie [Social Gerontology]. Grada Publishing.

Čeledová, L., Kalvach, Z., \& Čevela, R. (2016). Úvod do gerontologie [Introduction to Gerontology]. Univerzita Karlova v Praze, Karolinum. 
ČSÚ [CZSO]. (2020). Obyvatelstvo podle pohlaví a věkových skupin v obcích Moravskoslezského kraje $k$ 31. 12. 2018 [Population by Sex and Age in the Municipalities of the Moravian-Silesian Region as of 31.12.2018]. https://www.czso.cz/documents/11288/26139585/msk_vek_obyv_obce_18.pdf/3ed297ff-c564-49ff-99ec-5e65e823e3c2?version=1.1

ČSÚ [CZSO]. (2019). Počet obyvatel podle věkových skupin [Number of Citizens by Age]. http://apl.czso.cz/pll/eutab/html.h?ptabkod=tps00010

ČSÚ [CZSO]. (2018). Projekce obyvatelstva České republiky 2018-2100 [Czech Republic Population Projection 2018-2100]. https://www.czso.cz/csu/czso/projekce-obyvatelstva-ceske-republiky2018-2100

Eurostat (2020). Population by Age Group. https://ec.europa.eu/eurostat/databrowser/view/tps00010/default/table?lang=en

Hood, J. D. (2014). Orthodoxy vs. Power: The Defining Traits of Grounded Theory. In A. E. Clarke, \& K. Charmaz (Eds.), Grounded Theory and Situational Analysis. Volume I. History, Essentials and Debates in Grounded Theory (pp. 105-119). Sage.

Howard, L., \& Berg, B. L. (2016). Qualitative Research Methods for the Social Science. Pearson.

Hubík, S. (2006). Hypotéza [Hypothesis]. Jihočeská univerzita.

Hasmanová Marhánková, J. (2013) Aktivita jako projekt: diskurz aktivního stárnutí a jeho odezvy v životech českých senior a seniorek [Activity as a Project: Discourse of Active Ageing and Its Effect on the Life of Czech Senior Citizens]. Sociologické nakladatelství.

Haškovcová, H. (2010). Fenomén stáři [The Phenomenon of Old Age]. Havlíček Brain Team.

Lincoln, Y., Lynham, S., \& Guba, E. (2014). The Oxford Handbook of Qualitative Research. Oxford University Press.

Madridský mezinárodní akční plán stárnutí 2002 [The 2002 Madrid International Plan of Action on Ageing] (2002). https://www.mpsv.cz/documents/20142/372805/madrid.pdf/bd37397e-d804a44c-d69a-5d27882c252b

Maxwell, J. A. (2005). Qualitative Evaluation and Research Methods. Sage.

Moorse J. M. (2009). Developing Grounded Theory: The Second Generation. Left Coast Press.

MPSV [MoLSA]. (2019). Implementace politiky stárnutí na krajskou úroveň [Implementation of Ageing Policy at the Regional Level]. https://www.esfcr.cz/projekty-opz//asset_publisher/ODuZumtPTtTa/content/implementace-politiky-starnuti-na-krajskouuroven?inheritRedirect $=$ false

MPSV [MoLSA] (2015). Politika př́pravy na stárnutí v České republice [Policy on Preparation for Ageing in the Czech Republic]. https://www.mpsv.cz/documents/20142/225517/Politika_pripravy_na_starnuti_v_CR.pdf/c4ba305 4-bd5f-42c3-9805-1da55b4f91a8

Národní akční plán podporujici pozitivní stárnutí pro období let 2013 až 2017 [National Action Plan of Positive Ageing for the Period 2013-2017] (2014). https://www.mpsv.cz/documents/20142/372809/NAP_311214.pdf/0cc270fa-dbf9-fcd5-93d6$5 \mathrm{e} 7 \mathrm{~b} 0 \mathrm{e} 9376 \mathrm{~b} 2$

Národní program prípravy na stárnutí na období let 2003 až 2007 [National Programme of Preparation for Ageing for the Period 2003-2007]. (2002). https://www.mpsv.cz/narodni-program-pripravyna-starnuti-na-obdobi-let-2003-az-2007

Národní program připravy na stárnutí 2008 až 2012 [National Programme of Preparation for Ageing for the Period 2008-2012] (2008). https://www.databaze-strategie.cz/cz/mpsv/strategie/narodniprogram-pripravy-na-starnuti-2008-2012?typ=struktura

Návrh Střednédobého plánu rozvoje sociálnich služeb v Moravskoslezském kraji na léta 2021-2023 [Draft of the Medium-Term Plan for the Development of Social Services in the Moravian-Silesian Region for the Years 2021-2023] (2019). https://www.msk.cz/cz/socialni_oblast/odborna-i-laickaverejnost-ma-moznost-pripominkovat-navrhy-krajskych-strategickych-dokumentu-v-oblastisocialni--137919/

Padgett, D. (2017). Qualitative Methods in Social Work Research (3rd edition). Sage.

Pospíšil, D. (2015). Národni strategie rozvoje sociálních služeb na období 2016-2025 [Social Services Development National Strategy 2016-2025]. MPSV. 
Quadagno, J. (2017). Loose Leaffor Aging The Life Course. McGraw-Hill Education.

Strategie př́pravy na stárnutí společnosti 2019-2025 [Strategy on Preparation for Ageing 2019-2025] (n.d.). http://www.krestanstiseniori.cz/getattachment/Aktualne/Aktuality/2019/-STRATEGIEPRIPRAVY-NA-STARNUTI-SPOLECNOSTI-2019-20/Strategie-pripravy-na-starnutispolecnosti-2019-2025.pdf.aspx

Strategie rozvoje Moravskoslezského kraje na léta 2019-2027 [Strategy for Developing the MoravianSilesian Region for the Period 2019-2027]. (2019). http://www.hrajemskrajem.cz/wpcontent/uploads/2019/11/Upraven\%C3\%BD-n\%C3\%A1vrh-Strategie-rozvoje-MSK-20192027.pdf

Strauss, S., \& Corbin, J. (Eds.). (1997). Grounded Theory in Practice. Sage Publications.

Sýkorová, D. (2007). Autonomie ve stárí: kapitoly z gerontosociologie [Autonomy in Old Age: Chapters from Gerontosociology]. Sociologické nakladatelství Slon.

Swinnen, A., \& Stotesbury, J. A. (2012). Ageing, Performance, and Stardom: Doing Age on the Stage of Consumerist Culture. LIT.

Tomeš, I. (2018). Povinná sociální solidarita [Mandatory Social Solidarity]. Univerzita Karlova, Karolinum.

Úmluva o ochraně lidských práv a základních svobod [Convention on the Protection of Human Rights and Fundamental Freedoms] (1950). https://www.coe.int/en/web/conventions/full-list//conventions/treaty/005

Vávrová, S. (2015). Decision-making in Seniors Regarding Residential Social Services. Procedia Social and Behavioral Sciences. https://publikace.k.utb.cz/bitstream/handle/10563/1007044/Fulltext_1007044.pdf?sequence=1\&isAllowed=y

Zásady OSN pro seniory [UN Principles for Older Persons] (1991). https://www.mpsv.cz/zasady-osn-proseniory 